\title{
Effect of Fly Ash application on Microbial Population in Acid Soil
}

\author{
E. Nivetha* and S. Sheeba \\ Department of Soil Science and Agricultural Chemistry, Tamil Nadu Agricultural University, \\ Coimbatore -3, Tamil Nadu, India \\ *Corresponding author
}

\begin{tabular}{|c|c|}
\hline \multicolumn{2}{|r|}{ A B S T R A C T } \\
\hline & \multirow{6}{*}{ 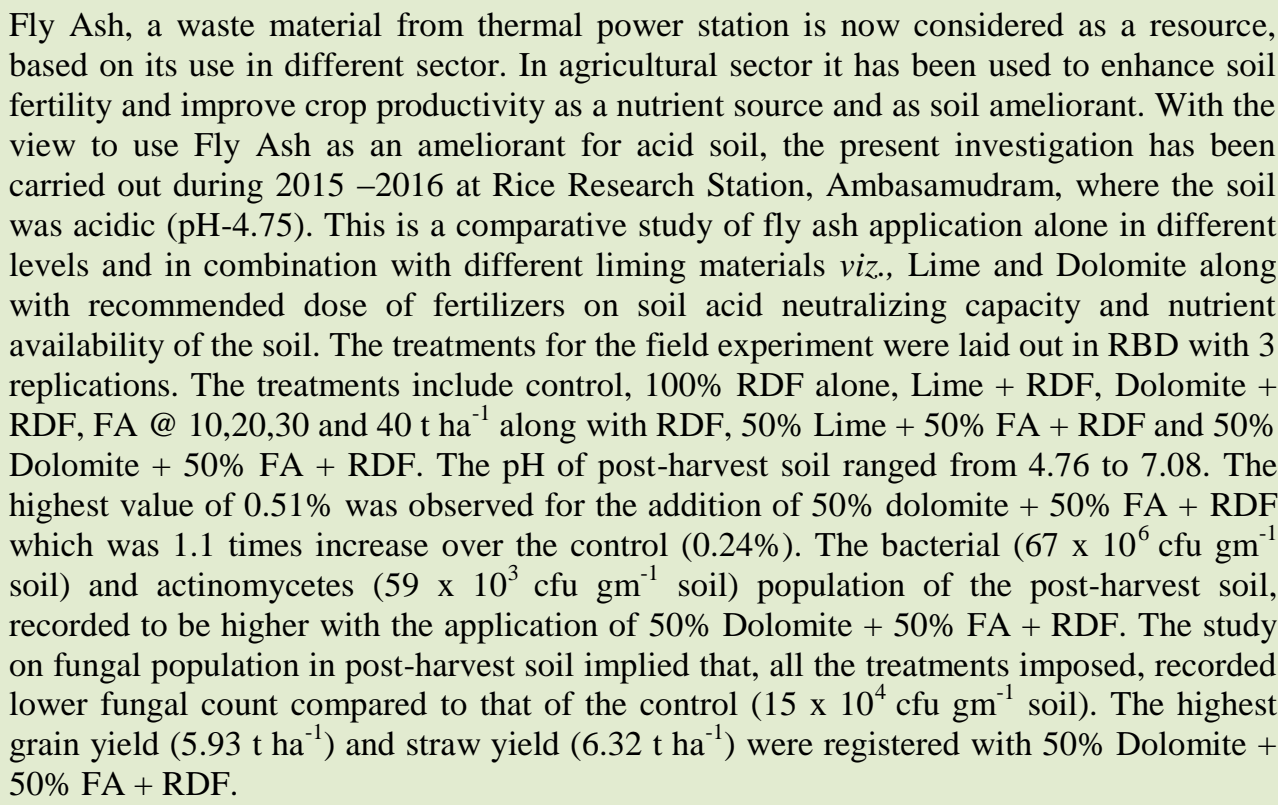 } \\
\hline & \\
\hline & \\
\hline Article Info & \\
\hline $\begin{array}{l}\text { Accepted: } \\
\text { 10 October } 2017 \\
\text { Available Online: } \\
10 \text { December } 2017\end{array}$ & \\
\hline & \\
\hline
\end{tabular}

\section{Introduction}

Fly Ash, an inorganic coal combustion residue from thermal power station is discussed to have all essential plant nutrients in available form for plants. Fly ash, due to their alkaline nature, buffer soil $\mathrm{pH}$ in an acid soil and favour the growth of soil microbes.

These beneficial soil microbes in turn enhance soil nutrient transformation and fertility which lead to increased crop production. Thus, with this background, present study has been carried out with fly ash on post-harvest soil's microbial population.

\section{Materials and Methods}

A comparative field study was taken up to study the effect of FA and other liming materials like lime and dolomite on alleviating soil acidity and improving soil fertility. The treatments of this study include, absolute control, 100\% RDF alone, lime + 
RDF, dolomite + RDF, FA @ 10, 20, 30 and $40 \mathrm{t} / \mathrm{ha}+\mathrm{RDF}, 50 \%$ lime + 50\%FA + RDF and $50 \%$ dolomite $+50 \% \mathrm{FA}+\mathrm{RDF}$. These 10 treatments ( $\mathrm{T} 1$ to $\mathrm{T} 10$ ) were tried in Randomized block design with 3 replications and Rice (variety - ASD 16) was used as test crop. The dosages for lime, dolomite and FA were fixed with $\mathrm{Ca}$ equivalence using lime buffer method by shoemaker et al., (1961). The FA used in this study was collected from Tuticorin thermal power station, Tamil Nadu, India and it was found to be alkaline with a $\mathrm{pH}$ of 8.6. It was also analysed for other chemical properties. The $\mathrm{pH}$ and $\mathrm{EC}$ values of the fly ash were 8.6 and 1.7 respectively. The initial soil was also analysed for its chemical properties. The $\mathrm{pH}$ and $\mathrm{EC}$ values of the initial soil were observed to be 4.65 and 0.50 respectively. The post-harvest soil was analysed for bacterial, fungal and actinomycetes population following the procedure of Waksman and Fred (1922) and $\mathrm{pH}$ (potentiometry) and Organic carbon (Walkley and Black, 1934). The results were statistically analysed using Aggress software at 5\% level of significance (Table 1 and 2).

\section{Results and Discussion}

\section{Soil pH}

The highest soil pH of 7.08 was recorded with application of $50 \%$ Dolomite $+50 \%$ FA + RDF followed by $50 \%$ Lime $+50 \%$ FA + RDF (6.90) (Table 3). The treatment FA @ 40 $\mathrm{t} \mathrm{ha}^{-1}$ recorded the $\mathrm{pH}$ of 6.23 and was on par with the application of Lime + RDF (6.05) and Dolomite + RDF (6.13). This might be due to the alkaline nature of FA used. The liming potential of Fly Ash is derived from the hydrolysis of $\mathrm{CaO}$ and $\mathrm{MgO}$, the major constituents of Fly Ash. These basic oxides in Fly Ash reacting with water in presence of $\mathrm{CO}_{2}$ form hydroxyl ions and Carbonates precipitate (Siddharth et al., 2011). These basic hydroxides in turn increase soil $\mathrm{pH}$. The treatment receiving $100 \%$ RDF alone recorded lower $\mathrm{pH}$ and was on par with control (4.76) with the value of 4.95.

\section{Organic carbon}

The organic carbon $\%$ of post-harvest soils ranged from $0.24 \%$ to $0.51 \%$ (Fig. 1). The highest value of $0.51 \%$ was observed for the addition of $50 \%$ dolomite $+50 \% \mathrm{FA}+\mathrm{RDF}$ which was 1.1 times increase over the control $(0.24 \%)$. This was then followed by treatments receiving $50 \%$ lime $+50 \% \mathrm{FA}+$ RDF and FA @ 40 t/ha + RDF which were on par with the values of 0.44 and $0.41 \%$ respectively. The lowest value was noticed for the treatment $100 \% \mathrm{RDF}$ alone $(0.25 \%)$, lime $+\operatorname{RDF}(0.26 \%)$ and dolomite $+\operatorname{RDF}(0.27 \%)$ which were on par with the control $(0.24 \%)$. This increase in OC\% with increments of fly ash might be due to the un-burnt coal present in fly ash (Kumar, 2002).

\section{Bacterial population}

Regarding the bacterial population of the post-harvest soil, the treatment $50 \%$ dolomite $+50 \%$ FA + RDF was highly significant with

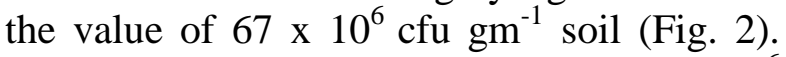
The Second highest bacterial count $\left(54 \times 10^{6}\right.$ cfu $\mathrm{gm}^{-1}$ soil) was implied with the application of FA @ 40 t/ha + RDF. The least count was registered with the control $\left(9 \times 10^{6}\right.$

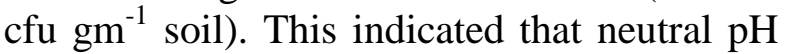
is more important than the nutritional aspect for bacterial growth as reported by Fettel et al., (1998).

\section{Fungal population}

The study on Fungal population in postharvest soil implied that, all the treatments imposed, recorded lower Fungal count compared to that of the control $\left(15 \times 10^{4} \mathrm{cfu}\right.$ $\mathrm{gm}^{-1}$ soil) (Fig. 2). The control plot was highly significant over the imposed treatments. 
Table.1 Physical, physico-chemical and chemical properties of fly ash

\begin{tabular}{|c|c|c|}
\hline S.No. & Properties & Value \\
\hline A. & PHYSICAL PROPERTIES & \\
\hline 1. & 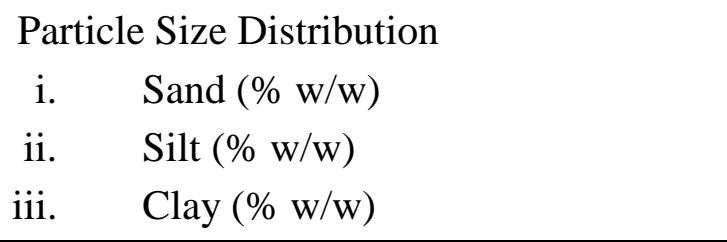 & $\begin{array}{l}65.25 \\
26.50 \\
6.25\end{array}$ \\
\hline 2. & Bulk Density $\left(\mathrm{Mg} \mathrm{m}^{-3}\right)$ & 1.05 \\
\hline 3. & Particle Density $\left(\mathrm{Mg} \mathrm{m}^{-3}\right)$ & 2.22 \\
\hline 4. & Total Porosity $(\%)$ & 52.0 \\
\hline B. & PHYSICO-CHEMICAL PROPERTIES & \\
\hline 1. & $\mathrm{pH}$ & 8.6 \\
\hline 2. & $\mathrm{EC}(\mathrm{ds} / \mathrm{m})$ & 1.7 \\
\hline 3. & Cation exchange capacity $\left(\mathrm{cmol}\left(\mathrm{p}^{+}\right) \mathrm{kg}^{-1}\right)$ & 20.0 \\
\hline C. & CHEMICAL PROPERTIES & \\
\hline 1. & Organic carbon $(\%)$ & 0.30 \\
\hline 2. & Total N (\%) & 0.003 \\
\hline 3. & Total P (\%) & 0.36 \\
\hline 4. & Total K (\%) & 0.86 \\
\hline 5. & Available $\mathrm{N}\left(\mathrm{mg} \mathrm{kg}^{-1}\right)$ & 35.0 \\
\hline 6. & Available $\mathrm{P}\left(\mathrm{mg} \mathrm{kg}^{-1}\right)$ & 116.0 \\
\hline 7. & Available $\mathrm{K}\left(\mathrm{mg} \mathrm{kg}^{-1}\right)$ & 179.0 \\
\hline 8. & Available $\mathrm{Ca}\left(\mathrm{mg} \mathrm{kg}^{-1}\right)$ & 30.0 \\
\hline 9. & Available $\mathrm{Mg}\left(\mathrm{mg} \mathrm{kg}^{-1}\right)$ & 10.0 \\
\hline 10. & DTPA Zn $\left(\mathrm{mg} \mathrm{kg}^{-1}\right)$ & 1.5 \\
\hline 11. & DTPA Fe $\left(\mathrm{mg} \mathrm{kg}^{-1}\right)$ & 21.0 \\
\hline 12. & DTPA Cu $\left(\mathrm{mg} \mathrm{kg}^{-1}\right)$ & 1.6 \\
\hline 13. & DTPA Mn $\left(\mathrm{mg} \mathrm{kg}^{-1}\right)$ & 1.8 \\
\hline 14. & Total $\mathrm{Cr}\left(\mathrm{mg} \mathrm{kg}^{-1}\right)$ & 0.03 \\
\hline 15. & Total Cd $\left(\mathrm{mg} \mathrm{kg}^{-1}\right)$ & 0.02 \\
\hline 16. & Total $\mathrm{Ni}\left(\mathrm{mg} \mathrm{kg}^{-1}\right)$ & 0.40 \\
\hline 17. & Acid insolubles (\%) & 53.5 \\
\hline
\end{tabular}


Table.2 Initial characterization of experimental soil

\begin{tabular}{|l|l|c|}
\hline S.No & \multicolumn{1}{|c|}{ Properties } & \\
\hline A. & PHYSICAL PROPERTIES & \\
1. & Particle size distribution(Sandy Loam) & \\
& i. Sand $(\% \mathrm{w} / \mathrm{w})$ & 61.60 \\
& ii. Silt $(\% \mathrm{w} / \mathrm{w})$ & 25.00 \\
$2 . \quad$ iii. Clay $(\% \mathrm{w} / \mathrm{w})$ & 10.58 \\
3. & Bulk density $\left(\mathrm{Mg} \mathrm{m}^{-3}\right)$ & 1.28 \\
4. & Particle density $\left(\mathrm{Mg} \mathrm{m}^{-3}\right)$ & 2.25 \\
B. & Total porosity $(\%)$ & 45.3 \\
1. & PHYSICO - CHEMICAL PROPERTIES & \\
2. & pH $\left.(\mathrm{dS} \mathrm{m})^{-1}\right)$ & 4.75 \\
3. & Cation exchange capacity (cmol $\left.\left(\mathrm{p}^{+}\right) \mathrm{kg}^{-1}\right)$ & 0.50 \\
C. & \multicolumn{1}{|c}{ CHEMICAL PROPERTIES } & 31.0 \\
1. & Organic carbon $(\%)$ & \\
2. & Available N $\left(\mathrm{kg} \mathrm{ha}^{-1}\right)$ & 0.23 \\
3. & Available P $\left(\mathrm{kg} \mathrm{ha}^{-1}\right)$ & 185 \\
4. & Available K $\left(\mathrm{kg} \mathrm{ha}^{-1}\right)$ & 70.0 \\
5. & Available Ca $\left(\mathrm{mg} \mathrm{kg}^{-1}\right)$ & 230.0 \\
6. & Available Mg $\left(\mathrm{mg} \mathrm{kg}^{-1}\right)$ & 12.5 \\
7. & DTPA Fe $\left(\mathrm{mg} \mathrm{kg}^{-1}\right)$ & 4.50 \\
8. & DTPA Mn $\left(\mathrm{mg} \mathrm{kg}^{-1}\right)$ & 20.70 \\
9. & DTPA Zn $\left(\mathrm{mg} \mathrm{kg}^{-1}\right)$ & 10.43 \\
10. & DTPA Cu $\left(\mathrm{mg} \mathrm{kg}^{-1}\right)$ & 0.88 \\
& \multicolumn{2}{|c|}{0.63} \\
\hline
\end{tabular}

Table.3 Effect of fly ash and other liming materials on soil reaction $(\mathrm{pH})$ of post-harvest soil

\begin{tabular}{|c|c|}
\hline Treatment & pH \\
\hline T1 & 4.76 \\
\hline T2 & 4.95 \\
\hline T3 & 6.05 \\
\hline T4 & 6.13 \\
\hline T5 & 5.58 \\
\hline T6 & 5.72 \\
\hline T7 & 5.83 \\
\hline T8 & 6.23 \\
\hline T9 & 6.90 \\
\hline T10 & 7.08 \\
\hline Mean & $\mathbf{5 . 9 2}$ \\
\hline SEd & $\mathbf{0 . 3 4}$ \\
\hline CD(p=0.05) & $\mathbf{0 . 7 2}$ \\
\hline
\end{tabular}


Table.4 Effect of fly ash and other liming materials on yield $\left(\mathrm{t} \mathrm{ha}^{-1}\right)$ of rice crop

\begin{tabular}{|c|c|c|}
\hline Treatments & grain $\left(\mathrm{t} \mathrm{ha}^{-1}\right)$ & straw $\left(\mathrm{t} \mathrm{ha}^{-1}\right)$ \\
\hline T1 & 3.84 & 5.10 \\
\hline T2 & 4.09 & 5.27 \\
\hline T3 & 4.72 & 5.38 \\
\hline T4 & 4.97 & 5.34 \\
\hline T5 & 5.26 & 5.45 \\
\hline T6 & 5.45 & 5.63 \\
\hline T7 & 4.63 & 5.29 \\
\hline T8 & 4.47 & 5.20 \\
\hline T9 & 5.72 & 6.10 \\
\hline T10 & 5.93 & 6.32 \\
\hline Mean & 4.9 & 5.5 \\
\hline SEd & 0.29 & 0.32 \\
\hline$C D(p=0.05)$ & 0.61 & 0.68 \\
\hline
\end{tabular}

Fig.1 Effect of fly ash and other liming materials on \%OC of post-harvest soils

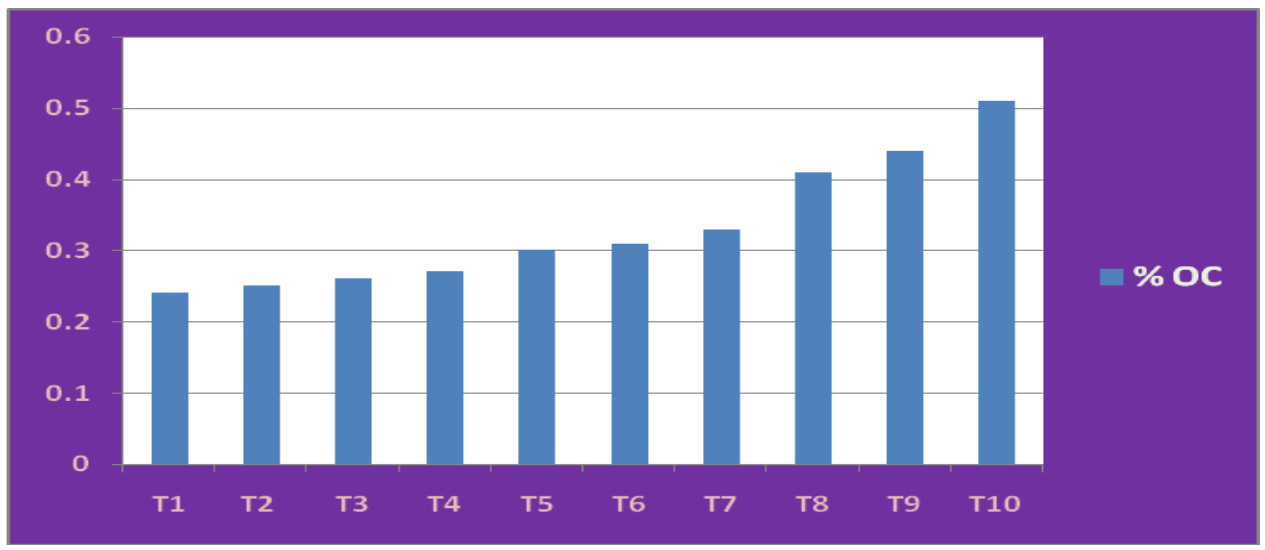

Fig.2 Effect of fly ash and other liming materials on microbial population $\left(\mathrm{Cfu} \mathrm{gm}^{-1}\right)$ of postharvest soil

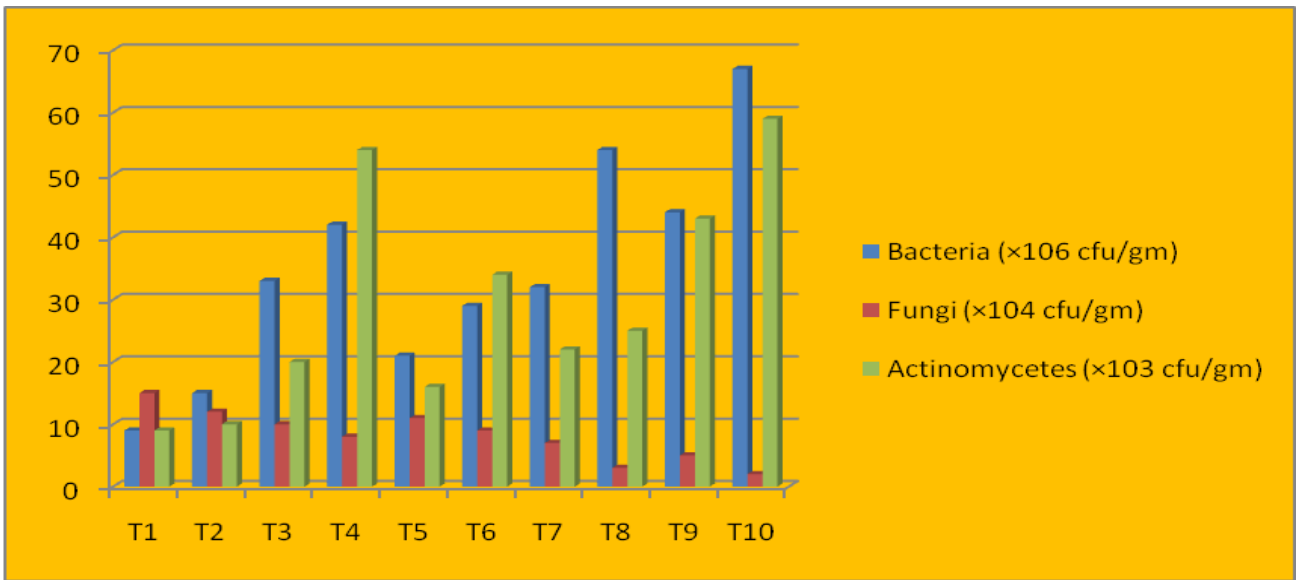


The least counts were registered with the application of FA @ $40 \mathrm{t} \mathrm{ha}^{-1}+\mathrm{RDF}$ and $50 \%$ dolomite + 50\% FA + RDF which were on par with the values 3 and $2 \times 10^{4} \mathrm{cfu} \mathrm{gm}^{-1}$ soil respectively. On the whole, the fungal populations were low compared to that of bacterial population due to increase in soil $\mathrm{pH}$ which was in line with the findings of Chandrakar et al., (2015).

\section{Actinomycetes population}

With regard to Actinomycetes population in post-harvest soil, application of 50\% dolomite $+50 \%$ FA + RDF was highly significant over other treatments with $59 \times 10^{3} \mathrm{cfu} \mathrm{gm}^{-1}$ soil (Fig. 2). This was then followed by dolomite + RDF with $54 \times 10^{3} \mathrm{cfu}^{-1}$ soil. The least count was shown by the application of $100 \%$ RDF alone $\left(10 \times 10^{3} \mathrm{cfu} \mathrm{gm}^{-1}\right.$ soil $)$ which was on par with the control $\left(9 \times 10^{3} \mathrm{cfu} \mathrm{gm}^{-1}\right.$ soil $)$. This is supported with the fact that the increased organic carbon in limed plots might have been conducive for the actinomycetes growth (Shah et al., 1990).

\section{Crop yield}

The highest grain yield $\left(5.93 \mathrm{tha}^{-1}\right)$ and straw yield $\left(6.32 \mathrm{t} \mathrm{ha}^{-1}\right)$ were registered with $50 \%$ Dolomite $+50 \%$ FA + RDF which was then followed by $50 \%$ Lime $+50 \% \mathrm{FA}+\mathrm{RDF}$ (grain yield- $5.72 \mathrm{t} \mathrm{ha}^{-1}$ and straw yield- $6.10 \mathrm{t}$ $\mathrm{ha}^{-1}$ ) (Table 4). The higher yield with the application of $50 \%$ Dolomite $+50 \%$ FA + RDF might be due to the good bacterial and actinomycetal population in the concerned plot.

The lower crop yield with FA at higher levels might be due to formation of physical barrier for root elongation with compaction of FA particles at higher levels (Dwivedi et al., 2007). But the yields for FA @ 30 and $40 \mathrm{t}$ $\mathrm{ha}^{-1}+\mathrm{RDF}$ were not lesser than the control plot and plot receiving 100\% RDF alone.
From the present study it is inferred that the Fly ash by buffering soil $\mathrm{pH}$ can favour the growth of soil microbes in an acid soil. The application of $50 \%$ dolomite $+50 \% \mathrm{FA}+$ $\mathrm{RDF}$ can be recommended to enhance soil bacterial and actinomycetes population whereas for fungal population Lime or Dolomite + RDF and FA @ $20 \mathrm{t} \mathrm{ha}^{-1}$ can be good.

\section{References}

Chandrakar T, Jena D, Dash A K, Jena S N, Panda N and Monica M. 2015. Soil microbial activity as influenced by application of fly ash and soil amendments to maize crop in acidic alfisols. International Research Journal of Agricultural Science and Soil Science, 5(4): 120-128.

Dwivedi, S., Tripathi, R.D., Srivasatava, S., Mishra, S., Shukla, M.K., Tiwari, K.K., Singh, R. and Rai, U.N. 2007. Growth performance and biochemical responses of three rice (Oryza sativa L.) cultivars grown in fly ash amended soil. Chemosphere, 67: 147-151.

Fettel NA, O'Connor GE, Carpenter DJ, Evans J, Bamforth I, Oti- Boateng C, Hebb DM, Brockwell J (1998). Nodulation studies on legume exotic to Australia: the influence of soil populations and inocula of Rhizobium leguminoserum bv. Viciae and nitrogen fixation by field peas. Applied Soil Ecol. 5: 197-310.

Kumar N. 2002. Growth response in crops raised in fly ash amended soil. Poll. res., 21: 409.

Shah Z, Adans W A and Haven C D V. (1990). Consumption and activity of the microbial population in an acidic upland soil and effects of liming. Soil Biology and Biochemistry. 22 (2):257-263.

Shoemaker H E, Mclean E O and Pratt P F.1961. Buffer methods for determining 
Lime requirement of soils with appreciable amounts of extractable aluminium. Soil Sci. Soc. Am Proc. 25:274 -278.

Siddharth Singh, Dadhibal Prasad Gond, Amit Pal B K, Tewary and Sinha A. 2011. World of Coal Ash Conference, Denver, USA.
Waksman S A and Fred E B. 1922. A tentative outline of the plate method for determining the number of microorganisms in soil. Soil Sci., 14:27-28.

Walkley A and Black C A. 1934. An estimation of methods for determining organic carbon and nitrogen in the soils. J. Agric. Sci., 25: 598-609.

\section{How to cite this article:}

Nivetha, E. and Sheeba, S. 2017. Effect of Fly Ash application on Microbial Population in Acid Soil. Int.J.Curr.Microbiol.App.Sci. 6(12): 888-894.

doi: https://doi.org/10.20546/ijcmas.2017.612.096 